\title{
A Comparative Study in the Poetry of Lorca and Forough Farrokhzad
}

\author{
Maryam Jalali (Corresponding author) \\ E-mail: Jalali_1388@yahoo.com \\ Hanifeh Ghobadi \\ Allameh Tabatabaee University, Tehran, Iran
}

Department of Persian Language and Literature at the Shahid Beheshti University. Tehran. Iran

Doi:10.7575/aiac.alls.v.7n.6p.178

URL: http://dx.doi.org/10.7575/aiac.alls.v.7n.6p.178
Received: 10/09/2016

Accepted: 15/11/2016

\begin{abstract}
If we study the shared themes of these two poets, it will be observed that although they are distant culturally and geographically but a similarity and a mental resemblance between their works can be identified. Forough Farrokhzad, the Persian poet, in whose last works experiences an evolutionary trend and actually achieves a thematic revolution, shares common themes with the Spanish poet which indicates that this Persian contemporary poet has been impressed by Lorca. "The star", the compound of "star", "love", "mermaid" and "bird" are among themes that are shared by both poets which shows the impressibility and connotation of Forough from lorca. On the other hand Intertextuality spread from culture to culture is influenced by various factors. It can demonstrate to the international literature.
\end{abstract}

Keywords: Persian poetry, impressibility, shared themes, Lorca, Forough Farrokhzad

\section{Introduction}

Sometimes people are far away from one another, but they share similar thoughts and emotions with each other in a different language. Such similar thoughts and implications consider the culture human communities.

The cultural pioneers have always had a more modern concept than the commoners and they illustrate a globally ideal society by stepping far beyond ethnic and moral traits. These similar concepts of two poets living far away from one another with extreme cultural differences might imply that poets may be affected from each other.

Forough Farrokhzad, an Iranian contemporary poet, has achieved a conceptual revolution in her previous poem books. She has depicted her main thoughts in her two recent books including: Tavalodi digar (Another Birth) and Bavar konim agaze fasle sard ra (Believe the beginning of the cold season) an also some of the concepts with almost stable attitudes in her first poem books. However, they are totally revolted in her next poems.

Forough has been profoundly affected by the poems of Tavalli, Naderpur, Moshiri and, etc in poems such as Captive notebooks, wall and violence and wrath with romantic theme (Shamisa, 1998:215).

There have been many factors completing the thought and poetic language of Forough. Some other researchers believe that this affectivity is caused by her being familiar with foreign poets like Pre Vow, Elvar V.T and S. Eliot. (Moshref Tehrani, 1998:451) Some concentrations on Forough's poems simply reveal the traces of Federico Garcia Lorca's poems, a prominent Spanish poet.

The similarities in her poems with Lorca's make the reader ponder whether they have been affected from one another? Although the very first translations of Lorca published in Iran little after Forough death, this cannot prove their affectivity. Even more, it has nothing to do with Forough' familiarity other languages like English, French, etc. The emergence of intertextuality is not limited merely symptoms. Sometimes the themes of the presentations comes intertextuality. Halliday believes that the text has the task of conveying meaning (Halliday, 1978: 110), In such cases, signs Literary, Social and Cultural emerge as intertextuality.

\section{The Biography of Forough}

Forough Farrokhzad was born in 1934 in Tehran. She moved to England in 1958 to study cinema. Later, she directed some films and starred in documentary movies. The turning point of her life is when she met Ebrahim Golestan and started working with him in movies. 


\section{The Biography of Lorca}

Federico Garcia Lorca, A Spanish poet, was born in 1898 in village called Granada. He spent his childhood and adolescence on music. He published his first book in verse in 1918 titled" In the Name of Beliefs and Sceneries in Granada". He performed his first play " The Nasty Time of Butterflies" in $1914 . \quad H e$ published his first poem book titled" A Book of Poems" in 1921. He has also issued some others like the gypsy's songs, the wedding of blood play, a poet in New York. The Astonishing wife and, etc. at the beginning of the civil war in Spain at the mid night of August 19, 1936, Lorca was shot by some anonymous ones believing that his poems were liberal and anti-fascism.

\section{The Evolution of Forough's Poem}

In her first three books (Captive notebooks, wall and violence and wrath), Forough had not reached her conceptual and language independency. He was defenseless against super-concepts that is why, she was seriously and clearly affected. During this time, she hadn't sharpened her poetic structure. She sometimes looked like Hafiz, sometimes Mowlavi, Khayyam or often Nima. In fact, Forough's character was not really identifiable and her actual meaning was not recognizable. (Roozbeh, 2006:159). After this time, Forough could achieve remarkable borders of purely poetic innovation and creativity relying on her courage and her deep poetic consistency which reflected in the poems of "Another Birth" and "Believe the beginning of the cold season". (Shamisa, 1998: 214 - 215) The most specification in her revolutionary era is explored while she began to break the poetic rules and traditions. Her postmodern artistic art and thought nurtured when she cooperated with Ebrahim Golestan, the contemporary story writer and scenarist. (Ibid :216)

\section{Similar Implications}

Analyzing the poems of Lorca and Forough reveal lots of implications in common like poetic compounds, expressions and concepts. Nell believes that credible emergence of intertextuality in literature of fact, it is similar to other texts (Neil, 1987: 25).

\section{Star}

star is one of the most favorable and remarkable elements of Forough as she has used this even in her first poem books. Star is the secret of happiness and joy in life. (Shamisa, 1998:193). Since star shimmers through darkness, it symbolizes spirit. Star actually represents a mental power fighting against darkness. (Ibid).

It should be pointed out that Forough has applied the concept of star like the one in all Persian poems:

Hey, stars high above/ though you are staring/ hey, stars watching the universe through far beyond the clouds/ (Asir1998)

Somewhere else, she says:

hey stars, you know the dishonesty and cruelty of human/ that have stuck to the heart of sky like this/ het stars, the very kind and heist stars (Ibid)

In other poem books the concept of star is suddenly changed and Forough commenced to create new poetic concepts based on her new understanding of star.

Dear Stars...The Dear Paper Star...../ when lies start blowing through the sky.../ how can believe in the verses of the defeated messengers...? (Forough, 2000)

In this piece of Forough's poem, she doesn't separate herself from the stars, but she doesn't believe in them, anymore (Moradi Kuchki, 2001:118). She no longer attributes lightness to them and considers them like paper which have no light and cannot be promising. This concept has been clearly observed in Lorca's poems, too:

Misfortunate stars? Stars with no light? What a grief / what a pain/ what a sorrow (Lorca. 2012: 146)

Forough remarks the stars the same as Lorca and recalls them: 'Dear Stars.../ Dear Paper Stars...'

This inters-textual theme is obviously implied and the reader simply comprehends it. These two poets are actually defining same thing that is they have lost their hope to the stars and they believe that stars are not promising anymore. Both poets have resembled stars to bird: in the moonlight- this sky spider- the flying stars are trapped...( Ibid) Young inexperienced stars/ have fallen from high to down....( Forough,2000)It should be remarked that Lorca has used the statement of' 'falling on the ground' hey, the defeated Oak tree/ four doves have fallen on the soil... (Ibid: 156)

Using red star is also another similar concept in the poems of these two poets:

I dreamed of that red star while I was awake"' (Ibid).

The same compound is found in Lorca's poems:

On this way/ her share is a red shining star/ because all stars.... (Lorca, 2007: 38) 


\section{The scar of love}

This theme is repeated exactly the same in Lorca and Forough's poem in wonderful way.

Love, love/I'm injured/injured of evasive love/injured/dead of love! (Lorca, 2012:14-15)

And all my scars are of love, of love, love, love! (Forough, 2000)

Due to this honesty, too many scars have pierced my soul or you can see whole my wounded sprit through this openness (Shimsa, 1998:51)

Repetition is one of the features of this poem (all poems of Forough). This feature increases the words rhythm and is an emphasis on the concepts(Ibid:51)

\section{Waiting}

Looking for a person capable of making the poet's wishes coming true has been brought in Lorca and Forough's poem. Signifacantly, expression mode of these poets is much similar:

I'm that person/the same is me.../everyone is of an individual character at last/and will be a person forever.../But no one is the same as the other one/the one who we're looking for...(Lorca,2001:32)

Some on is on the way/ Some on is on the way/someone else/someone better/one who looks like no one, isn't father, nor like a human, not John or mother/looks like the one who need to be... ! (Forough, 2000)

In both of excerpts, the poets are looking for someone else "the one who looks like no one". Lorca believes that none is the one we're looking for and about Forough, although is waiting for someone different from every one, has the same view of Lorca and believes that they are biting the air. "She has a saving dream in this poem which is the solution of all trivial and big problems"(Shimsa,1998:176) and inunciates the coming of this person only by a dream:

"I've dreamed of someone on the way" and "maybe she implies the falsehood of women's dream"(Ibid)

Disappointment in finding such an ideal person is apparent in these poems and both poets believe that they will never reach their personal goals and wishes.

\section{Teasing the lover on behalf of the beloved}

Being teased by beloved: being teased by beloved and poet's discontent of his beloved is often observed in our poetic tradition( Nikbakht,1993:107):

But the point is that Forough's tone and area of poem is just similar to Lorca's:

Why do you tease me? / Why? /If I were a fish/You'd better be a tide/or a moss.../why don't u make love to me? /why do you hinder my way? (Lorca,2001:12-13)

Hey sweetheart/hey unique sweetheart.../why do you always keep me on the bottom of the ocean? /look! How the fish nourish of my flesh! (Forough, 2000)

Dissatisfactory of current situation and discontent, is the content of these two excerpts. Lorca and Forough have complained with a common tone and content and objected their life situation. The depicted scene is the sea and both poets have narrated their story in such situation, Lorca complains of his sweetheart in this and ask her not to tease him and let everything goes well in this idealistic ocean and never hinder his way, while he wishes to be a fish. Forough also complains of her unique sweetheart in this ocean:

"Why do you always keep me at the bottom of the ocean?"(Ibid)

She as well as Lorca is toward going ahead and is sad of her sweetheart keeping her at the bottom of the ocean in this excerpt.

\section{Window}

The window is some kind of supposition and agent between human and the reality which the poet asserts that it can be solved with accuracy and attention and the reality is clarified. (Yousefinia,1994:131)

The concept of window is widely observed as a connection factor between the poet's world and the material world. This theme is seen in Lorca and Forough's poem. Of course, window has a common feature in poems of these poets and that is both poets can witness the happiness of others:

When I die/leave the moonlight window open/The child eats orange/ (I see him through the moonlight window)/the reaper reaps the wheat/ (I feel him through the moonlight window)/ When I die/ leave the moonlight window open.(Lorca,2007:96)

Forough says:

I'm talking about the heart of night/ I'm talking about the heart of the darkness/and the heart of the night/Hey, sweetheart, when coming to my home, bring me a light/ and a window through which/look at the crowd of lucky alley! (Forough, 2000)

"the light" is the secret of hope, luckiness and love and family focus. (Shimsa,1998:127)

In These two poems, Lorca and Forough talks about death and begins the poem with a doomy and saddening area. and both demand the reader a window open to the goodness, beauties and luckiness of others, a window through which she 
can see the child eating orange, reaping the wheat and shortly, a happy crowded alley. Although both poets are deprived of happiness, enjoy watching others happiness and joys.

\section{Mermaid}

Sea and the ocean are sometimes the secret of life and existence and sometimes the depth of a memory or signifies loneliness, alienage and death.( Ibid:125)

It's written in symbols dictionary that sea and ocean is an unconscious secret and ship is a tool that we go on an unconscious travel. Ocean is sometimes the symbol of woman or mother and returning to the sea means returning to the mother and death, it is also written that ocean equals general unconscious of which the soul sun rises. (Ibid)

Another common theme observed in these poet's poem, is taking the advantage of "mermaid" composition". Both poets talk about familiarity with this mermaid, one knows an old mermaid and another a young one:

You know the width of life secret/you always remind of/the legend of old mermaid/who heard the sound of plant growth...(Lorca,2013:18)

I know a young sad mermaid/dwelling in an ocean/and plays her heart slowly.../in a wooden flageolet/a young and sad mermaid who died of a kiss at night/and is born of a kiss on the daybreak! (Forough, 1998)

Lorca and Forough have analogized themselves to a mermaid and this analogy is interesting. In the first excerpt the poet imagines himself an old mermaid who hears even the sound of plant growth and this signifies the high intellect of poet from the world. Forough also analogizes herself to a young mermaid playing her heart in the flageolet of her poets and kiss, the symbol of love, causes death and rebirth of her after depicting the hollowness of her surroundings which is the signifier of her realization of the world.

\section{The bird}

According to yung, bird is the symbol of soul or angle and metaphysical aids, the bird is also the secret of thoughts and imagination rise.in Indian literature, the birds are the symbol of higher aspects.in mythologic imaginations, soul is a bird and we say that soul flied of chest cage (Shimsa,1998:114).

Bird as of Forough desired words and some of her poets are in related to bird. The last poem of Forough is "dying bird"(Ibid:115).

In this poem, Forough's language and thought is too close to Lorca's: It's because of my wings that I come back/let me fly/I want to pass away where the sun rises! /I want to die where it's still in the past/ It's because of my wings that I come back (Lorca,2005:208).

I'm depressed/I'm depressed/I go to the patio and touch the night stretched skin/the relations are not safe anymore/ (no one will show me the light)/no one take me to the sparrows' feast/learn how to fly/the birds are mortal. (Forough, 2000)

In these two poems, flight is the goal of both poets and sun... and also the death of both birds in these poems. Lorca says as a bird that like to die in the sun and Forough wants someone to show her the light, why the bird is mortal and for sure, she liked to die in the light. Lorca and Forough were a fan of flight, with a difference that Forough like this flight in a darker place, but both birds will die at last and the interesting point is that both poet have confessed to be aware of bird death. Lorca says: "I want to pass away where the sun rises" and Forough also confesses that bird is mortal and wish someone showing her the light.

In one of her interviews about the precious land, Forough says" it's a community by self. A community which is deprived of frank speech, at least with a witty and tomfoolery that is still allowed. In this poem, I've encountered some harsh and foolish issues.it isn't a must for a poem to be redolent. Let some poems to be in such a distance with romance that couldn't be the content of a letter to a beloved..."(Shimsa,1998:179).

In this poem, Forough talks about the formal symbols of our civil with humor. After years of striving, has taken her identity certificate and formally registered herself and address Iran, The prosperous land ironically (Ibid):

I became a conqueror/registered myself/now I'm relieved in every aspect/the warm arm of hometown/the papilla of honorable historical records/the lullaby of civil and culture and the sound of law rattler/Oh/I'm relieve in every aspect. (Forough, 1998).

In this poem, the poet calms one down by remembering the nice moments and the past honors and these are her only hope. Interesting point is that Forough uses a language and words just like Lorca's to remind of her hometown in a nostalgic way:

Deceiving him is easy/let's put our nipples softly/from now on/why a predetermined plan/is going to deceive us to sleep/when he has gone to asleep. (Lorca,2013:36)

Forough reminds of the honorable past of her hometown turning to a nipple for a temporary peace, of civil and culture as a deceiving lullaby for falling asleep and the rattle of law a tool for her silence.

Lorca also uses tools such as putting the nipple in the mouth, the rattle as a deceit and the silence of agog child, which is a symbol of the poet.

Preconsciousness/is the soul excavator/to secret and mystery/heart insight/groping/excavate the time in the dark/past is past/is the resting place of feeling and memory/the day before yesterday is passed/the den of dying thoughts/Unbridled 
pegasuses/the coppice of memories and the arid land/faded in the dust of dreams.../nothing will change the passed ecenturies.../ nor the bygones (Ibid:32-34).

Lorca also talks about the past of his land. In his view, past is past and the coppice of memories and the arid land have faded into the dust of dreams. But the poet believes that nothing will change the past centuries and honors. Forough also believes that the historical records of her hometown is worthwhile and although not in reach, reminding them is a tranquil to human being.

\section{Conclusion}

Several themes in the poetry of Lorca and Forough is a common in choosing the words and thought. Check the time and dates show, Lorca's poetry that is composed before Forough, and she is inspired by means of poems Lorca. It is important, both have been the lover, were susceptible, have used the elegant and romantic words. These words are so similar to each other in all of poems. The reason for this similarity may be similar social conditions. This is show the intertextuality in the works of them.

\section{References}

Farrokhzad, F. (1998). A collection of poems of Forough, Tehran: Fekre Rooz Press.

Farrokhzad, F. (2000). Believe the beginning of the cold season, Tehran,:Morvarid Press.

Halliday, M. (1978). Language as social. london: Arnold.

Lorca, F. (2007). Seasonal in Granada, (Translation Saeed Azin, Vahid beret), Tehran: Neghah Press.

Lorca, F. (2001). Romeo and Juliet stone bird, translation Chista yasrebi, Tehran:Namira Press.

Lorca, F. (2005). On the Moon and Death, translated critic Khosrow, Tehran: Ketab Roshan Press.

Lorca, F. (2012). Poet fascinated by the colors, the translation of Cheri Mir Sadeghi, Tehran: Niloofar Press.

Lorca, F. (2013). Selected Poems, translated by Zahra Rahbani, publishing inflorescence.

Lorca, F. (2002). Nor do I see it, the translation of the booty Glrvyy, Tehran, publishing Darynvsh.

Moradi Kochki, Sh. (2001). The letters Forough, Tehran, Gole Maryam.

Moshref, T., \& Pryshadkht, Sh. (1998). Life and Forough Farrokhzad, Tehran, Publishing Sales.

Nikbakht, M. (1993). To get rid missing, poetry and life Forough, Isfahan, Press Institute Mashal.

NeiL, H. (1987). Writings on Art and literature by Sigmund Freu.Standford University press.

Roozbeh, M. (2006). Contemporary literature, Tehran,: Roozgar publishing.

Shamisa, S. (1998). In the poem of Forough, Tehran, Morvarid press.

Yousefinia, S. (1994). In search of the blue, reflection on the Forough poetry. Tehran, publishing Meyar. 